\title{
HUBUNGAN KEDISIPLINAN GURU DENGAN KEDISIPLINAN BELAJAR PESERTA DIDIK KELAS V DI SD NEGERI SE-KECAMATAN KEBUMEN TAHUN AJARAN 2019/2020
}

\author{
Umi Roudoh', Suhartono², Ratna Hidayah ${ }^{3}$ \\ Universitas Sebelas Maret Surakarta \\ umiroudoh88@gmail.com
}

\section{Article History}

accepted 01/06/2020

approved 01/07/2020

published 01/08/2020

\begin{abstract}
The study aimed to determine correlation and contribution between teachers' discipline and discipline in learning on to fifth grade students of state elementary schools in Kebumen subdistrict in academic year of 2019/2020. It was quantitative research with a correlational research method. Data collection technique used questionnaires to 335 fifth grade students. Analysis of the data used simples correlation test and adjusted $R$ square with a significance level of $5 \%$. The results indicated that there was positive and significant relationship between teacher discipline and learning discipline with significance value of $0,000<0.05$. The correlation value was 0.481 . It meant that those variables had positive relationship. The adjusted $R$ square value of teacher discipline towards student learning discipline was $23.1 \%$ and the remaining $76.9 \%$ was influenced by other factors. It can be concluded that there is positive and significant relationship between teacher discipline learning discipline to fifth grade students of state elementary schools in Kebumen sub-district in academic year of 2019/2020.
\end{abstract}

Keywords: discipline, discipline teacher, student learning discipline

\begin{abstract}
Abstrak
Penelitian ini bertujuan untuk menemukan ada tidaknya hubungan dan besarnya sumbangan antara kedisiplinan guru dengan kedisiplinan belajar peserta didik di SD Negeri se-Kecamatan Kebumen tahun ajaran 2019/2020.Jenis penelitian yang digunakan yaitu kuantitatif dengan metode penelitian korelasi. Data dikumpulkan dengan cara penyebaran angket kepada 335 peserta didik kelas $V$. Analisis data dengan uji korelasi sederhana dan sumbangan efektif (SE) dengan taraf signifikansi 5\%. Hasil penelitian ini menunjukkan terdapat hubungan yang positif dan signifikan antara kedisiplinan guru dengan kedisiplinan belajar dengan nilai signifikansi $0,000<0,05$. Nilai korelasi sebesar 0,481 yang berarti kedua variable memiliki hubungan positif. Nilai sumbangan efektif variabel profesionalisme guru bersertifikasi terhadap hasil belajar yaitu $23,1 \%$ dan sisanya $76,9 \%$ dipengaruhi oleh faktor lain. Berdasarkan hasil penelitian tersebut dapat disimpulkan bahwa terdapat hubungan positif dan signifikan antara kedisiplinan guru dengan kedisiplinan belajar peserta didik kelas V di SD Negeri se- Kecamatan Kebumen tahun ajaran 2019/2020.
\end{abstract}

Kata kunci: kedisiplinan, kedisiplinan guru, kedisiplinan belajar peserta didik 


\section{PENDAHULUAN}

Kementrian Pendidikan Nasional merumuskan 18 nilai karakter yang harus ditanamkan pada peserta didik dalam upaya membentuk karakter bangsa. Salah satu nilai karakter tersebut adalah kedisiplinan (Suyadi, 2013: 8). Disiplin merupakan ketaatan dan kepatuhan untuk menghormati dan melaksanakan suatu aturan, keputusan dan perintah (Tidjani dalam Naim, 2012: 142). Widodo (2013: 142) menyampaikan bahwa disiplin memiliki kecenderungan yang bersifat membimbing dan menciptakan suatu kondisi yang dapat meningkatkan pertumbuhan dan prestasi siswa. Disiplin menunjukkan perilaku yang sopan, cinta ketertiban, keinginan untuk melaksankan tugas dengan keteraturan dan efisiensi, dan rasa tanggung jawab yang tinggi (Mumthas, Jouhar \& Abdul, 2014: 301).

Di era modern seperti sekarang ini, nilai pendidikan karakter sudah mulai luntur. Hartini (2017: 38) berpendapat bahwa hal tersebut dapat dibuktikan dengan banyaknya perbuatan yang menyimpang aturan khususnya dilakukan oleh pelajar. Perbuatan yang menyimpang tersebut yaitu tidak disiplin, berbicara kotor, melanggar aturan sekolah, membolos sekolah, hilangnya sopan santun, dan berkelahi. Wulyandani, dkk. (2014: 288) mengemukakan bahwa perilaku penyimpangan kedisiplinan sering ditemui di lingkungan sekolah, termasuk sekolah dasar. Sebagai contoh perilaku penyimpangan tersebut antara lain: terlambat datang ke sekolah, menginjak tanaman, mengumpulkan tugas tidak tepat waktu, tidak berangkat sekolah tanpa keterangan, tidak memakai seragam yang sesuai dengan aturan sekolah, tidak membuang sampah pada tempatnya, dan mengotori dinding sekolah.

Penelitian mengenai kedisiplinan belajar peserta didik telah dilakukan oleh Hartini (2017). Dalam penelitian tersebut didapatkan data bahwa salah satu karakter yang ditanamkan di Madrasah Kabupaten Klaten yaitu kedisiplinan. Pentingnya penanaman nilai kedisiplinan tersebut dikarenakan banyaknya perilaku peserta didik di Madrasah yang tidak sesuai dengan norma disiplin. Sebagai contoh yaitu meninggalkan sekolah tanpa izin, tidak membuang sampah pada tempatnya, tidak tepat waktu dalam mengumpulkan tugas, dan tidak tepat waktu datang ke sekolah.

Pembentukan kedisiplinan dapat ditempuh melalui pendidikan kedisiplinan di sekolah. Pendidikan kedisiplinan hendaknya dilakukan sejak dini melalui penerapan tata tertib, perintah yang tegas, meningkatkan kebiasaan baik pada peserta didik yang tidak merugikan diri sendiri ataupun orang lain (Elly, 2016: 44). Wulyandani, dkk., (2014: 288) berpendapat bahwa pendidikan kedisiplinan merupakan hal yang penting dalam membentuk karakter peserta didik. Jika peserta didik mempunyai nilai kedisiplinan maka karakter-karakter baik lainnya akan muncul, seperti kejujuran, tanggung jawab, kerjasama, dan lainnya.

Guru sebagai pendidik sepatutnya menjadi model bagi peserta didiknya. Dikatakan demikian, kata guru diambil dari istilah bahasa Jawa yaitu "digugu" dan "ditiru". Kata "digugu" memiliki arti dipercaya sedangkan "ditiru" memiliki arti dicontoh. Dengan demikian, guru sepatutnya menjadi contoh untuk mengarah pendidikan yang berbudaya, berkarakter dan bermoral untuk mengantarkan peserta didik menuju bangsa yang beradab (Setyowati, dkk., 2018: 15). Oleh karena itu, seorang guru hendaknya dapat menegakkan kedisiplinan dan memiliki sikap bertanggung jawab dengan tugas yang telah diberikan kepadanya. Hal tersebut supaya peserta didik memiliki kedisiplinan dalam belajar di sekolah. Jika seorang peserta didik memiliki kedisiplinan belajar tersebut maka dapat menumbuhkan karakter baik lainya dari peserta didik itu sendiri.

Berdasarkan hasil observasi dan wawancara awal didapatkan data bahwa pada kelas V SD Negeri Candimulyo pembelajaran masih berpusat pada guru, guru belum memanfaatkan perpustakaan sekolah dengan baik, tingkat kedisiplinan guru perlu ditingkatkan. Tidak hanya tingkat kedisiplinan guru yang perlu ditingkatkan, tetapi kedisiplinan peserta didik pun perlu ditingkatkan seperti peserta didik lupa tidak 
mengerjakan PR atau tugas sekolah, terlambat berangkat ke sekolah dan kurang memperhatikan penjelasan guru ketika pembelajaran berlangsung. Selain itu, minat membaca, dan minat belajar perlu dioptimalkan. Penelitian mengenai kedisiplinan guru telah dilakukan oleh Dahril (2017) dan Iswan \& Indah (2019). Dalam penelitian tersebut diketahui bahwa kedisiplinan guru berpengaruh terhadap kedisiplinan belajar peserta didik.

Berdasarkan latar belakang di atas maka peneliti tertarik untuk mengadakan penelitian kuantitatif yang bertujuan untuk: (1) Untuk menemukan adanya hubungan positif kedisiplinan guru terhadap kedisiplinan belajar peserta didik kelas $\mathrm{V}$ di SD Negeri se-Kecamatan Kebumen tahun ajaran 2019/2020, (2) Untuk menemukan besarnya sumbangan kedisiplinan guru terhadap kedisiplinan belajar peserta didik kelas V di SD Negeri se-Kecamatan Kebumen tahun ajaran 2019/2020.

\section{METODE}

Penelitian ini menggunakan pendekatan kuantitatif metode korelasi yang dilakukan di SD Negeri se-Kecamatan Kebumen. Populasi pada penelitian ini yaitu semua peserta didik kelas V di SD Negeri se-Kecamatan Kebumen sebanyak 1598. Pengambilan sampel pada penelitian dilakukan dengan metode cluster sampling yang terdiri dari dua belas SD Negeri dengan jumlah 335 peserta didik. Teknik pengumpulan data menggunakan metode angket. Angket digunakan untuk pengumpulan data penelitian pada variabel bebas yaitu kedisiplinan guru variabel terikat yaitu kedisiplinan belajar peserta didik. . Data hasil penelitian diuji dengan menggunakan uji normalitas dan uji linearitas yang selanjutnya diuji dengan menggunakan uji korelasi sederhana dan sumbangan efektif.

\section{HASIL DAN PEMBAHASAN}

Berdasarkan penelitian yang telah dilakukan pada tanggal 24 Februari - 13 Maret 2020 di dua belas SD Negeri dengan jumlah 335 peserta didik diperoleh data berupa analisis uji korelasi sederhana dan sumbangan efektif. Data yang diperoleh ketika penelitian yang terdiri dari variabel kedisiplinan guru $(X)$ dan kedisiplinan belajar peserta didik $(Y)$ diuji korelasinya dengan menggunakan uji korelasi pearson. Hasil analisis uji korelasi sederhana dapat dilihat pada tabel 1:

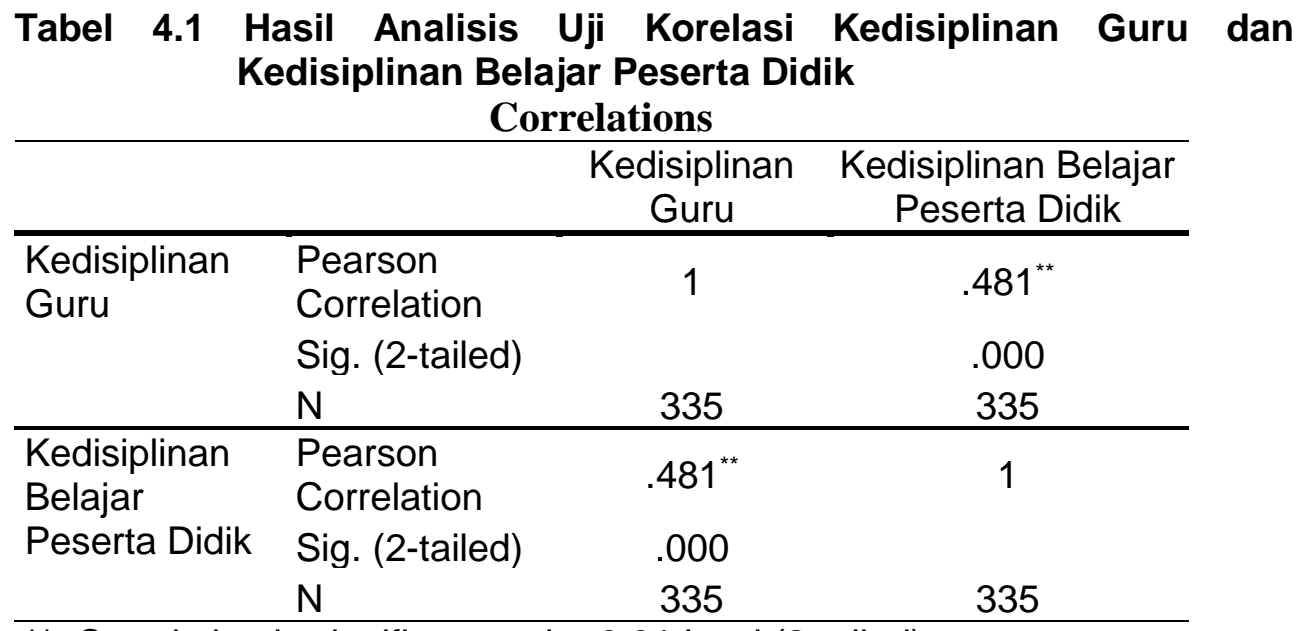

${ }^{* *}$. Correlation is significant at the 0.01 level (2-tailed).

Berdasarkan tabel 1 dapat diketahui bahwa nilai Sig. yaitu $\mathbf{0 , 0 0 0}$. Oleh karena itu, dapat disimpulkan bahwa nilai Sig. 0,000 $<\alpha(0,05)$, yang berarti menolak $\mathrm{H}_{0}$ dan 
menerima $\mathrm{H}_{1}$ sehingga terhadap hubungan positif antara variabel kedisiplinan guru dengan kedisiplinan belajar peserta didik kelas V di SD Negeri se-Kecamatan Kebumen tahun ajaran 2019/2020.

Berdasarkan penelitian dan perhitungan yang telah dilakukan dapat diketahui bahwa kedisiplinan guru memiliki hubungan positif dengan kedisiplinan belajar peserta didik. Oleh karena itu, dapat dikatakan bahwa semakin tinggi kedisiplinan guru maka semakin tinggi pula kedisiplinan belajar peserta didik. Begitupun sebaliknya, semakin rendah kedisiplinan guru maka semakin rendah kedisiplinan belajar peserta didik. Nurfadillah, (2016: 41) berpendapat bahwa terdapat lima indikator kedisiplinan guru, yaitu: 1) mematuhi tata tertib sekolah, 2) disiplin waktu, 3) memiliki sikap yang tegas, 4) disiplin dalam berpakaian, 5) disiplin dalam mengajar.

Sebagai seorang guru, semua perilaku dan sikap yang dilakukannya tentu dapat dilihat dan dicontoh oleh peserta didiknya. Oleh karena itu, seorang guru harus memiliki kedisiplinan, karena peserta didik akan disiplin jika seorang guru memiliki kedisiplinan (Aini, 2017: 23). Dalam menanamkan disiplin kepada peserta didik maka seorang guru harus memulai dari dirinya sendiri dalam berbagai tindakan dan perbuatan. Salah satu yang termasuk di dalamnya yaitu menggunakan seragam sesuai dengan peraturan yang ada. Guru dituntut untuk selalu berpakaian rapi dan sopan, karena guru merupakan suri tauladan bagi peserta didiknya, dimana gerak seorang guru akan selalu dinilai oleh peserta didiknya (Idris dalam Nurfadillah, 2016: 15-17).

Guru memiliki peran yang sangat penting dalam menunjang perubahan peserta didik menuju lebih baik. Sikap yang tegas menjadi dominan dalam proses membentuk peserta didiknya menjadi peserta didik yang memiliki kedisiplinan belajar yang baik. Jika peserta didik melakukan kesalahan, guru memberikan tindakan berupa sanksi dengan tegas (Idris dalam Nurfadillah, 2016: 15-16). Kedisiplinan belajar peserta didik meliputi melaksanakan tata tertib sekolah dengan baik, taat dalam mengerjakan tugas, memperhatikan dengan baik saat pembelajaran berlangsung, dan tertib dan taat saat belajar di rumah dan di kelas.

Seorang guru juga harus mampu menggunakan dan membagi waktu dengan baik. Waktu masuk sekolah menjadi salah satu parameter utama kedisiplinan seorang guru. Usahakan guru dapat tepat waktu masuk sekolah, begitu pula dengan jam mengajar yang sesuai dengan alokasi waktu yang telah ditentukan agar tidak mengganggu jam guru lain (Idris dalam Nufadilah, 2016: 16-17). Jika guru memiliki disiplin waktu yang baik maka kedisiplinan belajar peserta didik akan baik. Salah satunya yaitu taat dalam mengerjakan tugas yang diberikan oleh guru.

Disiplin dalam mengajar merupakan faktor yang penting dalam rangka pencapaian keberhasilan belajar mengajar. Guru berperan sebagai pengelola dalam pembelajaran dan sebagai fasilitator yang berusaha menciptakan kondisi yang efektif sehingga memungkinkan proses pembelajaran dengan baik, mengembangkan materi pembelajaran dengan baik, dan meningkatkan kemampuan peserta didik untuk memperhatikan pelajaran (Idris dalam Nurfadillah, 2016: 18). Jika guru memiliki disiplin dalam mengajar, maka peserta didik akan memperhatikan dengan baik saat pembelajaran berlangsung, tertib dan taat saat belajar di rumah dan di kelas, dan taat dalam mengerjakan tugas.

Hasil penelitian ini sesuai dengan penelitian yang dilakukan oleh Dahril (2017: 90) tentang "Pengaruh Kedisiplinan Guru terhadap Kedisiplinan Belajar Siswa pada Mata Pelajaran Fikih di Madrasah Tsanawiyah Darul Hikmah Pekanbaru" bahwa terdapat pengaruh yang signifikan kedisiplinan guru (variabel $\mathrm{x}$ ) terhadap kedisiplinan belajar siswa (variabel y) pada mata pelajaran Fikih di Madrasah Tsanawiyah Darul Hikmah Pekanbaru. Hal ini dapat dilihat dari $r_{\text {hitung }}=0,625$ dengan kontribusi 39,06\%.

Selain itu hasil penelitian ini juga diperkuat dengan penelitian yang dilakukan oleh Iswan dan Indah (2019: 125) tentang "Pengaruh Disiplin Kerja Guru terhadap Disiplin Belajar Siswa Sekolah Dasar" bahwa terdapat pengaruh yang cukup signifikan 
antara disiplin kerja guru terhadap disiplin belajar siswa kelas IV Sekolah Dasar Negeri Sawangan 02 Depok yang menunjukkan angka korelasi sebesar $0.409>r_{\text {tabel }} 0.374$ pada taraf signifikansi $5 \%$. Karena nilai uji korelasi menunjukkan $r_{\text {hitung }}>$ dari $r_{\text {tabel }}$ maka dapat dinyatakan bahwa hipotesis terdapat pengaruh terhadap disiplin belajar siswa diterima.

Berdasarkan uraian di atas, dapat disimpulkan bahwa hasil penelitian ini telah sesuai dengan teori yang ada dan didukung pula dengan penelitian yang relevan, maka hasil penelitian ini adalah terdapat hubungan positif dan signifikan antara kedisiplinan guru dengan kedisiplinan belajar peserta didik kelas V di SD Negeri seKecamatan Kebumen tahun ajaran 2019/2020.

Berdasarkan hasil perhitungan sumbangan efektif pada variabel kedisiplinan guru dan kedisiplinan belajar peserta didik didapatkan hasil sebesar 23,1\%, artinya kedisiplinan guru dapat berperan dalam meningkatkan kedisiplinan belajar peserta didik sebesar $23,1 \%$ dan sisanya sebesar $76,9 \%$ dipengaruhi oleh faktor lain. Hasil penelitian ini sesuai dengan penelitian yang dilakukan Iswan \& Indah (2019: 125) menyatakan bahwa bahwa sumbangan efektif variabel disiplin kerja guru terhadap disiplin belajar siswa kelas IV Sekolah Dasar Negeri Sawangan 02 Depok ialah sebesar $16,7 \%$ dan sisanya sebesar $83,3 \%$ dipengaruhi faktor lain.

\section{SIMPULAN}

Berdasarkan hasil penelitian dan pembahasan mengenai hubungan kedisiplinan guru dengan kedisiplinan belajar peserta didik kelas V di SD Negeri se-Kecamatan Kebumen tahun ajaran 2019/2020 dapat ditarik kesimpulan bahwa kedisiplinan guru memiliki hubungan positif dan signifikan dengan kedisiplinan belajar peserta didik kelas $V$ di SD Negeri se-Kecamatan Kebumen tahun ajaran 2019/2020 dan besar sumbangan efektif variabel kedisiplinan guru $(X)$ terhadap kedisiplinan belajar peserta didik (Y) yaitu 23,1\% dan sisanya 76,9\% dipengaruhi oleh faktor lain.

Upaya untuk meningkatkan kedisiplinan guru dapat melalui pembuatan aturan yang disepakati bersama, pempinan sekolah sekolah yang memiliki kedisiplinan baik, guru mengisi buku absen atau agenda kelas, dan mengumumkan frekuensi pelanggaran yang dilakukan oleh guru saat rapat.

Berdasarkan kesimpulan dan implikasi di atas, beberapa saran yang dapat peneliti sampaikan yaitu: (1) guru hendaknya selalu mempertahankan dan meningkatkan kedisiplinan agar dapat menumbuhkan kedisiplinan belajar peserta didik, (2) kepala sekolah hendaknya memberikan motivasi kepada guru dan peserta didik agar kedisiplinan di sekolah tersebut lebih ditingkatkan dan kepala sekolah juga harus memberikan pembinaan kepada guru yang terlambat, (3) bagi peneliti yang ingin melakukan penelitian yang hampir sama dengan judul penelitian ini dapat menjadi acuan dalam penelitian korelasi dan diharapkan mencari sumber referensi lainnya agar nanti penelitiannya akan jauh lebih baik.

\section{DAFTAR PUSTAKA}

Aini, S. (2017). Pengaruh Kedisiplinan Guru terhadap Karakter Siswa dalam Belajar di Madrasah Tsanawiyah Al-Washliyah Ismailiyah No. 82 Medan (Doctoral dissertation, Universitas Islam Negeri Sumatera Utara), 23.

Dahril, M. (2017). Pengaruh Kedisiplinan Guru terhadap Kedisiplinan Belajar Siswa pada Mata pelajaran Fikih di Madrasah Tsanawiyah Darul Hikmah Pekanbaru (Doctoral dissertation, Universitas Islam Negeri Sultan Syarif Kasim Riau), 90. 
Elly, R. (2016). Hubungan Kedisiplinan terhadap Hasil Belajar Siswa Kelas V di SD Negeri 10 Banda Aceh. Jurnal Pesona Dasar, 3(4), 44.

Hartini, S. (2017). Pendidikan Karakter Disiplin Siswa di Era Modern Sinergi Orang Tua dan Guru di MTS Negeri Kabupaten Klaten. AL-ASASIYYA: Journal Of Basic Education, 2(1), 38.

Iswan, I., \& Indah, H. (2019). Pengaruh Disiplin Kerja Guru terhadap Disiplin Belajar Siswa Sekolah Dasar. Refleksi Edukatika: Jurnal Ilmiah Kependidikan, 10(1), 125.

Mumthas, N.S., Munavvir, J., \& Abdul Gafoor, K. (2014). Student and Teacher Perception of Disciplinary Practices: Types, Reason, Consequences and Alternatives. Online Submisson, 2(4), 301-308.

Naim, N. (2012). Character Building. Yogyakarta: Ar-Ruzz Media

Nurfadillah. (2016) Pengaruh Kedisiplinan Guru terhadap Motivasi Belajar Siswa di SMA Negeri 1 Sengkang Kab.Wajo. Skripsi Tidak Dipublikasikan. UIN Alauddin Makassar, 15-41.

Setyowati, I.R., Isminatun., Purwaningsih, R.S., Setyo, B., Sri, S., Titiek, W. (2018). Ragam Implementasi Pendidikan Karakter Sekolah. Sukoharjo: CV Farishma Indonesia, 15.

Suyadi. (2013). Strategi Pembelajaran Pendidikan Karakter. Bandung: PT. Remaja Rosdakarya, 8.

Widodo, B. (2013). Perilaku Disiplin Siswa Ditinjau dari Aspek Pengendalian Diri (Self Control) dan Keterbukaan Diri (Self Disclosure) pada Siswa SMK Wonoasri Caruban Kabupaten Madiun. Widya Warta, 37(01), 142.

Wulyandani, W., Bunyamin, M., Sapriya., \& Dasin, B. (2014). Pendidikan Karakter Disiplin di Sekolah Dasar. Cakrawala Pendidikan, Juni 2014, Th. Xxxiii, No. 2, 288. 